\title{
Factors Associated with Adherence to Antiretroviral Drugs among HIV Positive Patients Attending Selected Comprehensive Care Centers in Semi- Urban, Kenya
}

\author{
Martin Owuor Ochieng ${ }^{1}$, Gideon Kikuvi ${ }^{2}$ Daniel Mokaya ${ }^{3}$ \\ ${ }^{1}$ Postgraduate Student-Jomo Kenyatta University of Agriculture and Technology, Kenya. \\ ${ }^{2}$ Professor /Coordinator of Postgraduate Studies- Jomo Kenyatta University of Agriculture and Technology, \\ Kenya. \\ ${ }^{3}$ Senior Lecturer- Jomo Kenyatta University of Agriculture and Technology, Kenya.
}

Corresponding Author: Martin Owuor Ochieng

\begin{abstract}
Management of Human Immunodeficiency Virus (HIV) is multipronged but its nerve centre is lifelong adequate and consistent use of antiretroviral drugs (ARVs). The overall objective of this study was to determine the factors associated with adherence to antiretroviral drugs among HIV positive patients attending selected Comprehensive Care Centres (CCC) in Kibwezi West Sub-county, Makueni County, Kenya. 385 respondents were recruited by systematic random sampling and interviewed. Three Focused Group Discussions (FGD) and two Key Informant Interviews (KII) were also conducted. Majority $364(94.5 \%)$ of the respondents were adherent to ARVs. There was a significant association between adherence to ARVs and gender $\left\{\chi^{2}(1)=4.636, p<0.05\right\}$ with males likely to have poor adherence $\{$ OR $0.174(95 \%$ CI $0.130,0.233)\}$. Age was significantly associated with adherence $\left\{\right.$ Likelihood Ratio $\mathrm{G}^{2}(4)=10.693$, $\left.\mathrm{p}<0.05\right\}$ with older ages (above 65 years) likely to adhere. Living in the same house with someone on ARVs was significantly associated with adherence to ARVs $\left\{\chi^{2}(1)=3.997 \mathrm{p}=<0.05\right\}$ with respondents living in the same house with someone on ARVs likely to adhere $\{$ OR $0.144(95 \%$ CI $0.103,0.200)\}$. Majority of the respondents had adequate knowledge and positive attitude towards adherence to ARVs. FGDs and KIIs identified fear, stigma, not believing in oneself, participating in activities that hamper adherence such as drinking alcohol, ignorance, denial, lack of social support, busy work schedule poor attitude by health service providers, drug stock outs, distance and long waiting time as contributing to poor adherence to ARVs. In conclusion, constant education and awareness creation on importance of adherence to ARVs should be strengthened particularly during clinic appointments to maintain knowledge and enhance positive attitude towards adherence. Measures to improve adherence among the male and younger population should be strengthened.
\end{abstract}

Key Words: adherence, antiretrovirals age, gender, knowledge, attitude

\section{INTRODUCTION}

Management of Human Immunodeficiency Virus (HIV) is multipronged but the nerve centre of it is lifelong adequate and consistent use of antiretroviral drugs (ARVs). Poor adherence to ARVs is a significant public health concern in the control of (HIV) infection.
Understanding factors contributing to good adherence to ARVs is crucial in strengthening methods to improve adherence. Research shows that adherence to ARVs increases longevity and maintains an individual's optimal functionality in ways comparable to a healthier counterpart. (1) Heestermans et al posits that the success 
of HIV treatment includes both access and adherence to ARVs by individuals enrolled into care. ${ }^{(2)}$ In order to achieve optimum treatment outcomes, an adherence rate of $95 \%$ is required. ${ }^{(3)}$ There have been great inroads by governments and international organizations such as the World Health Organization (WHO) in ensuring access to ARVs and free HIV treatment; however, drug adherence remains a significant challenge.

The general objective of the study was to determine the factors associated with adherence to antiretroviral drugs among HIV positive patients aged 15 years and above attending selected CCCs in Kibwezi West sub-county, Makueni County, Kenya. The specific objectives were: to determine the prevalence of adherence to ARVs; to determine socio-demographic and socioeconomic factors associated with adherence to ARVs; to determine behavioural factors associated with adherence to ARVs and to determine clinical and facility level factors associated with adherence to ARVs among HIV positive patients attending selected CCCs in
Kibwezi West sub-county, Makueni County, Kenya.

Counties in Kenya have varying levels of adherence rates among HIV infected adult population on ARVs. Makueni County houses the longest stretch of the busy Mombasa-Nairobi Highway. Kibwezi West sub-county has major administrative and commercial towns along the Mombasa-Nairobi highway that contribute significantly to the national burden of HIV/AIDS. The towns are also stop-overs for long-distance truck drivers; a key population in contributing significantly to high HIV prevalence along the transport corridor. Kenya's Vision 2030 describes HIV as one of the greatest threats to achieving socio-economic development. ${ }^{(4)}$ Poor adherence to ARVs further makes socioeconomic development a mirage as it is associated with worse health outcomes. Notably, HIV/AIDS accounted for the sixth top ten causes of death by the year $2014 .{ }^{(5)}$ Poor adherence accelerates progression to AIDS; thus, undermining United Nations' Sustainable Development Goal (SDG) 3.3 that aims at ending AIDS epidemics by $2030{ }^{(6)}$

Table 1: Literature review findings

\begin{tabular}{|c|c|c|c|c|c|}
\hline Author(s) & Title & $\begin{array}{l}\text { Type } \\
\text { article }\end{array}$ & Journal & $\begin{array}{l}\text { Level of } \\
\text { Evidence }\end{array}$ & Relevant Findings \\
\hline $\begin{array}{l}\text { Heestermans } \\
\text { et al., } 2016\end{array}$ & $\begin{array}{l}\text { Determinants of adherence } \\
\text { to antiretroviral therapy } \\
\text { among HIV-positive adults } \\
\text { in sub-Saharan Africa: a } \\
\text { systematic review. }\end{array}$ & $\begin{array}{l}\text { Systematic } \\
\text { Review and } \\
\text { Meta-analysis }\end{array}$ & $\begin{array}{l}\text { BMJ Global } \\
\text { Health }\end{array}$ & Level V & $\begin{array}{l}\text { Study shows an adherence estimate of } \\
72.9 \% \% \text {. }^{(2)}\end{array}$ \\
\hline $\begin{array}{ll}\text { Soomro } & \text { et } \\
\text { al., } 2019\end{array}$ & $\begin{array}{l}\text { Comparison of } \\
\text { Antiretroviral Therapy } \\
\text { Adherence Among HIV- } \\
\text { Infected Older Adults with } \\
\text { Younger Adults in Africa: } \\
\text { Systematic Review and } \\
\text { Meta-analysis }\end{array}$ & $\begin{array}{l}\text { Systematic } \\
\text { Review and } \\
\text { Meta-analysis }\end{array}$ & $\begin{array}{l}\text { AIDS and } \\
\text { Behaviour }\end{array}$ & Level V & $\begin{array}{l}\text { Older adults were more likely to adhere } \\
\text { to ARVs than younger adults. }{ }^{(7)}\end{array}$ \\
\hline $\begin{array}{ll}\text { Ammon } & \text { et } \\
\text { al., } 2018\end{array}$ & $\begin{array}{l}\text { Factors impacting } \\
\text { antiretroviral therapy } \\
\text { adherence among human } \\
\text { immunodeficiency virus- } \\
\text { positive adolescents in Sub- } \\
\text { Saharan Africa: a } \\
\text { systematic review }\end{array}$ & $\begin{array}{l}\text { Systematic } \\
\text { Review }\end{array}$ & Public Health & Level V & $\begin{array}{l}\text { Barriers to optimal adherence to ARVs } \\
\text { were stigma, ARV side effects, } \\
\text { forgetfulness and lack of assistance. } \\
\text { Facilitators of optimal adherence were } \\
\text { knowledge of HIV status, peer support } \\
\text { and caregiver support. }\end{array}$ \\
\hline $\begin{array}{l}\text { Croome } \\
\text { al., } 2017\end{array}$ & $\begin{array}{l}\text { Patient-reported barriers } \\
\text { and facilitators to } \\
\text { antiretroviral adherence in } \\
\text { sub-Saharan Africa }\end{array}$ & $\begin{array}{l}\text { Systematic } \\
\text { Review }\end{array}$ & AIDS & Level V & $\begin{array}{l}\text { Barriers to optimal adherence to ARVs } \\
\text { were forgetfulness, lack of access to } \\
\text { adequate food, travelling, being outside } \\
\text { the house, side effects, stigma and } \\
\text { discrimination. Facilitators of optimal } \\
\text { adherence were social support, disclosing } \\
\text { one's HIV status, feeling healthier after } \\
\text { taking ARVs, good relationship with } \\
\text { health care provider, reminders and } \\
\text { social support. }\end{array}$ \\
\hline
\end{tabular}


Martin Owuor Ochieng et.al. Factors associated with adherence to antiretroviral drugs among HIV positive patients attending selected comprehensive care centers in semi-urban, Kenya.

\begin{tabular}{|c|c|c|c|c|c|}
\hline \multicolumn{6}{|c|}{ Table 1 Continued... } \\
\hline $\begin{array}{l}\text { Mengesha et } \\
\text { al., } 2020\end{array}$ & $\begin{array}{l}\text { The association between } \\
\text { diagnosis disclosure and } \\
\text { adherence to antiretroviral } \\
\text { therapy among adolescents } \\
\text { living with HIV in sub- } \\
\text { Saharan Africa: a protocol } \\
\text { for systematic review and } \\
\text { meta-analysis }\end{array}$ & $\begin{array}{l}\text { Systematic } \\
\text { Review and } \\
\text { Meta-analysis }\end{array}$ & $\begin{array}{l}\text { Sytematic } \\
\text { Reviews }\end{array}$ & Level V & $\begin{array}{l}\text { Adherence to ARVs differs with } \\
\text { knowledge of one's own HIV status and } \\
\text { self-disclosure. }\end{array}$ \\
\hline $\begin{array}{l}\text { Bijker et al., } \\
2017\end{array}$ & $\begin{array}{l}\text { Adherence to antiretroviral } \\
\text { therapy for HIV in sub- } \\
\text { Saharan Africa and Asia: a } \\
\text { comparative analysis of two } \\
\text { regional cohorts }\end{array}$ & $\begin{array}{l}\text { Cohort } \\
\text { Prospective } \\
\text { Research }\end{array}$ & $\begin{array}{l}\text { Journal of } \\
\text { International } \\
\text { AIDS Society }\end{array}$ & Level II & $\begin{array}{l}\text { Sub-optimal adherence to ARVs was } \\
\text { greater in the African cohort. In the } \\
\text { African cohort predictors of sub-optimal } \\
\text { adherence were male sex, younger age, } \\
\text { use of concomitant medication and } \\
\text { attending public facility. Patient-reported } \\
\text { barriers to adherence to ARVs in the } \\
\text { African Cohort were forgetfulness, } \\
\text { scheduling demands, drug stock outs, } \\
\text { stigma, depression, pill burden, regimen } \\
\text { complexity, sickness or adverse } \\
\text { events. }{ }^{(11)}\end{array}$ \\
\hline $\begin{array}{l}\text { Chirambo et } \\
\text { al., } 2019\end{array}$ & $\begin{array}{l}\text { Factors influencing } \\
\text { adherence to antiretroviral } \\
\text { treatment among adults } \\
\text { accessing care from private } \\
\text { health facilities in Malawi }\end{array}$ & $\begin{array}{l}\text { Cross- } \\
\text { sectional } \\
\text { Qualitative } \\
\text { Study }\end{array}$ & $\begin{array}{l}\text { BMC Public } \\
\text { Health }\end{array}$ & Level III & $\begin{array}{l}\text { Patient factors as barriers to optimal } \\
\text { adherence were forgetfulness, better } \\
\text { perception of one's health, denial of } \\
\text { one's HIV status, fear of disclosure on } \\
\text { one's status, ARV side effects and ARV } \\
\text { fatigue. Health system level factors } \\
\text { contributing to suboptimal adherence } \\
\text { include poor relationship between } \\
\text { healthcare providers and clients, shortage } \\
\text { of trained health care workers in ART, } \\
\text { lack of finances and long distance to the } \\
\text { facilities. Predictors of good adherence } \\
\text { were psychological support, follow up } \\
\text { visits after missed opportunities, positive } \\
\text { relationship with health care providers, } \\
\text { education, adequate information and } \\
\text { counselling. }{ }^{(12)}\end{array}$ \\
\hline $\begin{array}{l}\text { Mukui et al., } \\
2016\end{array}$ & $\begin{array}{l}\text { Rates and Predictors of } \\
\text { Non-Adherence } \\
\text { Antiretroviral to } \\
\text { among Therapy } \\
\text { Individuals in Kenya: } \\
\text { Results from the Second } \\
\text { Kenya AIDS Indicator } \\
\text { Survey, 2012. }\end{array}$ & $\begin{array}{l}\text { Cross- } \\
\text { sectional } \\
\text { Quantitative } \\
\text { Study }\end{array}$ & PLOS ONE & Level III & $\begin{array}{l}\text { Less than } 10 \% \text { of Kenyans in Nairobi } \\
\text { County, Kenya's capital city were not } \\
\text { adhering to ARVs reflecting a significant } \\
\text { success in retention to care and treatment } \\
\text { response. }\end{array}$ \\
\hline $\begin{array}{ll}\text { Rouhani } & \text { et } \\
\text { al.,2017 }\end{array}$ & $\begin{array}{l}\text { The role of social support } \\
\text { on HIV testing and } \\
\text { treatment adherence: A } \\
\text { qualitative study of HIV- } \\
\text { infected refugees in south- } \\
\text { western Uganda. }\end{array}$ & $\begin{array}{l}\text { Cross- } \\
\text { sectional } \\
\text { Qualitative } \\
\text { Study }\end{array}$ & $\begin{array}{l}\text { Global Public } \\
\text { Health }\end{array}$ & Level III & $\begin{array}{l}\text { Individuals with higher social support } \\
\text { had better adherence. }^{(14)}\end{array}$ \\
\hline $\begin{array}{l}\text { Agbaji } \text { et al., } \\
2015\end{array}$ & $\begin{array}{l}\text { Treatment Discontinuation } \\
\text { in Adult HIV-Infected } \\
\text { Patients on First-Line } \\
\text { Antiretroviral Therapy in } \\
\text { Nigeria. } \\
\end{array}$ & $\begin{array}{l}\text { Cross- } \\
\text { sectional } \\
\text { Quantitative } \\
\text { Study }\end{array}$ & $\begin{array}{l}\text { Current } H I V \\
\text { research }\end{array}$ & Level III & $\begin{array}{l}\text { Positive association between younger age } \\
\text { and poor adherence. }{ }^{(15)}\end{array}$ \\
\hline $\begin{array}{ll}\text { Semvua } & \text { et } \\
\text { al., } 2017 & \end{array}$ & 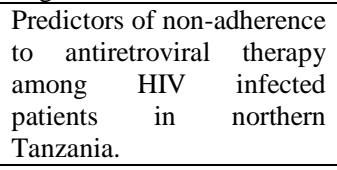 & $\begin{array}{l}\text { Cross- } \\
\text { sectional } \\
\text { Study }\end{array}$ & PLoS One & Level III & $\begin{array}{l}\text { Poor adherence was associated with } \\
\text { unemployment. }{ }^{(16)}\end{array}$ \\
\hline $\begin{array}{l}\text { Kim et al., } \\
2017\end{array}$ & $\begin{array}{l}\text { High self-reported non- } \\
\text { adherence to antiretroviral } \\
\text { therapy amongst } \\
\text { adolescents living with HIV } \\
\text { in Malawi: barriers and } \\
\text { associated factors }\end{array}$ & & $\begin{array}{l}\text { Journal of the } \\
\text { International } \\
\text { AIDS Society }\end{array}$ & & $\begin{array}{l}\text { There was no association between sex } \\
\text { and age and adherence. }{ }^{(17)}\end{array}$ \\
\hline $\begin{array}{l}\text { Adejumo et } \\
\text { al., } 2015\end{array}$ & $\begin{array}{l}\text { Contemporary issues on the } \\
\text { epidemiology and } \\
\text { antiretroviral adherence of } \\
\text { HIV-infected adolescents in } \\
\text { sub-Saharan Africa: a } \\
\text { narrative review. }\end{array}$ & Meta-analysis & $\begin{array}{l}\text { Journal of the } \\
\text { International } \\
\text { AIDS Society }\end{array}$ & Level V & $\begin{array}{l}\text { Older adolescents were more likely to } \\
\text { have poor adherence than other age } \\
\text { groups. lack of food, transportation costs, } \\
\text { unaffordable treatment fees, low family } \\
\text { purchasing power were associated with } \\
\text { poor adherence. }{ }^{(18)}\end{array}$ \\
\hline
\end{tabular}


Martin Owuor Ochieng et.al. Factors associated with adherence to antiretroviral drugs among HIV positive patients attending selected comprehensive care centers in semi-urban, Kenya.

\begin{tabular}{|c|c|c|c|c|c|}
\hline \multicolumn{6}{|c|}{ Table 1 Continued... } \\
\hline $\begin{array}{l}\text { Mukui et al., } \\
2016\end{array}$ & $\begin{array}{l}\text { Rates and Predictors of } \\
\text { Non-Adherence } \\
\text { Antiretroviral to } \\
\text { among Therapy } \\
\text { Individuals in Ken-Positive } \\
\text { Results from the Second } \\
\text { Kenya AIDS Indicator } \\
\text { Survey, 2012. }\end{array}$ & $\begin{array}{l}\text { Cross- } \\
\text { sectional } \\
\text { Quantitative } \\
\text { Study }\end{array}$ & PLOS ONE & Level III & $\begin{array}{l}\text { Younger age was positively associated } \\
\text { with poor adherence. Non-adherence was } \\
\text { noted to be higher among rural } \\
\text { population compared to the urban } \\
\text { population as well as those involved in } \\
\text { recreational drug use. }{ }^{(13)}\end{array}$ \\
\hline $\begin{array}{l}\text { Mûnene \& } \\
\text { Ekman, } 2016\end{array}$ & 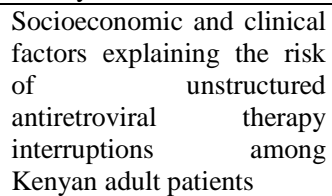 & $\begin{array}{l}\text { Cross- } \\
\text { sectional } \\
\text { Study }\end{array}$ & AIDS Care & Level III & $\begin{array}{l}\text { ARV treatment interruption was likely to } \\
\text { be more prevalent in individuals who } \\
\text { have been on treatment longer. }{ }^{(19)}\end{array}$ \\
\hline $\begin{array}{ll}\text { Tiruneh } & \text { et } \\
\text { al., } 2016 & \end{array}$ & $\begin{array}{l}\text { Retention in Care among } \\
\text { HIV-Infected Adults in } \\
\text { Ethiopia, 2005- 2011: A } \\
\text { Mixed-Methods Study. }\end{array}$ & $\begin{array}{l}\text { Mixed- } \\
\text { Methods Study }\end{array}$ & PLoS One & Level III & $\begin{array}{l}\text { Economic constraints negatively affect } \\
\text { retention to care; consequently poor } \\
\text { adherence to ARVs. }\end{array}$ \\
\hline $\begin{array}{l}\text { Yotebieng et } \\
\text { al., } 2016\end{array}$ & $\begin{array}{l}\text { Conditional Cash Transfers } \\
\text { to Increase Retention in } \\
\text { PMTCT } \\
\text { Antiretroviral Adherence, } \\
\text { and Postpartum Virological } \\
\text { Suppression: } \\
\text { A Randomized Controlled } \\
\text { Trial. }\end{array}$ & $\begin{array}{l}\text { Interventional } \\
\text { Study }\end{array}$ & $\begin{array}{l}\text { Journal of } \\
\text { Acquired } \\
\text { Immune } \\
\text { Deficiency } \\
\text { Syndromes }\end{array}$ & Level I & $\begin{array}{l}\text { Incentives did not significantly affect } \\
\text { adherence to ARVs. }\end{array}$ \\
\hline $\begin{array}{l}\text { Tweya } \text { et al., } \\
2018\end{array}$ & $\begin{array}{l}\text { Understanding factors, } \\
\text { outcomes and reasons for } \\
\text { loss to follow-up among } \\
\text { women in Option B+ } \\
\text { PMTCT programme in } \\
\text { Lilongwe, Malawi. }\end{array}$ & Cohort Study & $\begin{array}{l}\text { Tropical } \\
\text { Medicine \& } \\
\text { International } \\
\text { Health }\end{array}$ & Level II & $\begin{array}{l}\text { Most studies have not related WHO } \\
\text { clinical staging at enrolment and } \\
\text { adherence to ARVs. In this Malawian } \\
\text { study, WHO clinical stage } 3 \text { and } 4 \text { were } \\
\text { associated with an increased risk to loss } \\
\text { to follow up (LTFU). }\end{array}$ \\
\hline $\begin{array}{l}\text { Costenaro et } \\
\text { al., } 2015\end{array}$ & $\begin{array}{l}\text { Predictors of Treatment } \\
\text { Failure in HIV-Positive } \\
\text { Children receiving } \\
\text { Combination Antiretroviral } \\
\text { Therapy: Cohort Data From } \\
\text { Mozambique and Uganda. }\end{array}$ & Cohort Study & $\begin{array}{l}\text { Journal of the } \\
\text { Paediatric } \\
\text { Infectious } \\
\text { Diseases } \\
\text { Society }\end{array}$ & Level II & $\begin{array}{l}\text { WHO clinical stage } 4 \text { was associated } \\
\text { with a higher rate of treatment failure in } \\
\text { Uganda and Mozambique. }{ }^{(23)}\end{array}$ \\
\hline $\begin{array}{ll}\text { Gesesew } & \text { et } \\
\text { al.,2018 } & \end{array}$ & $\begin{array}{lr}\text { Early mortality among } \\
\text { children and adults in } \\
\text { antiretroviral therapy } \\
\text { programs in Southwest } \\
\text { Ethiopia }\end{array}$ & $\begin{array}{l}\text { Cross- } \\
\text { sectional } \\
\text { Study }\end{array}$ & PLoS One & Level III & $\begin{array}{l}\text { WHO stage } 3 \text { and } 4 \text { was associated with } \\
\text { a higher mortality rate compared to } \\
\text { WHO stage } 1 \text { and } 2 .{ }^{(24)}\end{array}$ \\
\hline $\begin{array}{l}\text { Ssebunya } \\
\text { al., } 2017\end{array}$ & $\begin{array}{l}\text { Antiretroviral therapy } \\
\text { initiation within seven days } \\
\text { of enrolment: outcomes and } \\
\text { time to undetectable viral } \\
\text { load among children at an } \\
\text { urban HIV clinic in } \\
\text { Uganda. }\end{array}$ & & $\begin{array}{l}\text { BMC } \\
\text { Infectious } \\
\text { Diseases }\end{array}$ & & $\begin{array}{l}\text { Adherence to ARVs and baseline WHO } \\
\text { clinical stage } 1 \text { and } 2 \text { were associated } \\
\text { with viral suppression. }{ }^{(25)}\end{array}$ \\
\hline $\begin{array}{l}\text { Dos \& } \\
\text { Wolvaardt } \\
2016\end{array}$ & $\begin{array}{l}\text { Integrated intervention for } \\
\text { mental health co-morbidity } \\
\text { in HIV-positive individuals: } \\
\text { A public health assessment }\end{array}$ & & $\begin{array}{l}\text { African } \\
\text { Journal of } \\
\text { AIDS } \\
\text { Research } \\
\text { (AJAR) }\end{array}$ & & $\begin{array}{l}\text { Psychological disorder was associated } \\
\text { with poor adherence to ARVs. }{ }^{(26)}\end{array}$ \\
\hline $\begin{array}{l}\text { Mangesho, et } \\
\text { al., } 2014\end{array}$ & $\begin{array}{l}\text { "Every drug goes to treat its } \\
\text { own disease..." - a } \\
\text { qualitative study of } \\
\text { perceptions and experiences } \\
\text { of taking anti-retrovirals } \\
\text { concomitantly with anti- } \\
\text { malarials among those } \\
\text { affected by HIV and } \\
\text { malaria in Tanzania. }\end{array}$ & $\begin{array}{l}\text { Cross- } \\
\text { sectional } \\
\text { Qualitative } \\
\text { Study }\end{array}$ & $\begin{array}{l}\text { Malaria } \\
\text { Journal }\end{array}$ & Level III & $\begin{array}{l}\text { Treatment with anti-malarial in HIV } \\
\text { infected patients did not affect adherence } \\
\text { to ARVs. }{ }^{(27)}\end{array}$ \\
\hline $\begin{array}{ll}\text { Ammon } & \text { et } \\
\text { al., } 2018\end{array}$ & $\begin{array}{l}\text { Factors impacting } \\
\text { antiretroviral therapy } \\
\text { adherence among human } \\
\text { immunodeficiency virus- } \\
\text { positive adolescents in Sub- } \\
\text { Saharan Africa: a } \\
\text { systematic review. }\end{array}$ & $\begin{array}{l}\text { Systematic } \\
\text { Review and } \\
\text { Meta-analysis }\end{array}$ & Public Health & Level V & $\begin{array}{l}\text { Knowledge about HIV status } \\
\text { associated with better adherence. }{ }^{(8)}\end{array}$ \\
\hline
\end{tabular}


Martin Owuor Ochieng et.al. Factors associated with adherence to antiretroviral drugs among HIV positive patients attending selected comprehensive care centers in semi-urban, Kenya.

\begin{tabular}{|c|c|c|c|c|c|}
\hline \multicolumn{6}{|c|}{ Table 1 Continued... } \\
\hline $\begin{array}{l}\text { Eshun- } \\
\text { Wilson } \text { et al., } \\
2019\end{array}$ & $\begin{array}{l}\text { Being HIV positive and } \\
\text { staying on antiretroviral } \\
\text { therapy in Africa: A } \\
\text { qualitative } \\
\text { review and theoretical } \\
\text { model. }\end{array}$ & $\begin{array}{l}\text { Systematic } \\
\text { Review and } \\
\text { Meta-analysis }\end{array}$ & PLoS One & Level V & $\begin{array}{l}\text { Punitive and uninviting perception of } \\
\text { hospitals makes patients have a bad } \\
\text { attitude towards ARV adherence. }{ }^{(28)}\end{array}$ \\
\hline $\begin{array}{l}\text { Dowse et al., } \\
2014\end{array}$ & $\begin{array}{lr}\text { Simple, } & \text { illustrated } \\
\text { medicines information } \\
\text { improves ARV knowledge } \\
\text { and patient self-efficacy in } \\
\text { limited literacy South } \\
\text { African HIV patients. }\end{array}$ & Cohort Study & AIDS Care & Level II & $\begin{array}{l}\text { Positive association between adherence } \\
\text { to ARVs and knowledge on HIV and } \\
\text { ARV. }{ }^{(29)}\end{array}$ \\
\hline $\begin{array}{l}\text { Okawa et al., } \\
2018\end{array}$ & $\begin{array}{l}\text { Psychological well-being } \\
\text { and adherence r to } \\
\text { antiretroviral therapy } \\
\text { among adolescents living } \\
\text { with HIV in Zambia }\end{array}$ & & AIDSCare & & $\begin{array}{l}\text { Lack of basic knowledge about HIV was } \\
\text { associated with poor adherence to } \\
\text { ARV. }{ }^{(30)}\end{array}$ \\
\hline Mprah, 2016 & $\begin{array}{l}\text { Knowledge, opinions, and } \\
\text { experiences of stigma as a } \\
\text { barrier to antiretroviral } \\
\text { therapy adherence among } \\
\text { HIV community volunteers } \\
\text { and health care givers in an } \\
\text { urban slum, in Uganda. }\end{array}$ & & $\begin{array}{l}\text { Annals of } \\
\text { Tropical } \\
\text { Medicine \& } \\
\text { Public Health }\end{array}$ & & $\begin{array}{l}\text { Knowledge about stigma in itself does } \\
\text { not improve adherence to ARVs. }{ }^{(31)}\end{array}$ \\
\hline $\begin{array}{l}\text { Ramadhani } \\
\text { et al., } 2016\end{array}$ & $\begin{array}{l}\text { Association of knowledge } \\
\text { on ART line of treatment, } \\
\text { scarcity of treatment } \\
\text { options and adherence. }\end{array}$ & & $\begin{array}{l}\text { BMC Health } \\
\text { Services } \\
\text { Research }\end{array}$ & & $\begin{array}{l}\text { Patient's knowledge of their } \\
\text { antiretroviral line of treatment and } \\
\text { limited future treatment options were } \\
\text { more likely to adhere. }{ }^{(32)}\end{array}$ \\
\hline
\end{tabular}

The variability of these findings points to the need of contextualizing determinants of poor adherence to population-specific studies.

\section{MATERIALS AND METHOD}

We conducted a cross-sectional study in selected comprehensive care centres in Kibwezi west sub-county, Makueni County, Kenya between the months of September 2019 to December 2019.The study population was HIV positive patients aged 15 years and above who met our inclusion criteria.

Sample size of 385 was determined by the Cochran formula ${ }^{(33)}$ with a significance level of 0.05), estimated prevalence rate from previous studies (average of 50\%) and a precision level of 0.05. Two CCC centres: Makindu SubCounty hospital and Emali model health centre were purposively sampled. Makindu town is majorly an administrative town while Emali town is majorly a commercial town thus provided a better and diverse picture in the study. Number of respondents in each CCC was proportionately determined and respondents attending the CCC clinics on their appointed dates were sampled by systematic random sampling.
Data was collected by interviewer administered Centre for Adherence Support Evaluation (CASE) questionnaire on adherence level confirmed by pill count and the last viral load. It assesses adherence level using a Likert-scale like questions where a score of $>10$ denotes adherent while $<10$ denotes non-adherent. Adherence in this study was defined as how one correctly takes medication or interventions as prescribed by a health care provider. (34) There are a variety of methods for measuring adherence. They include direct methods such body fluid assays, and biologic markers or indirect methods such as viral load monitoring, interview, selfreport, pharmacy records and pill counts. Whereas a combination of these methods may be used, self-report is the most widely employed (35) due to its ease of implementation and studies show that it correlates well with both viral load and clinical picture. ${ }^{(36,37)}$

The questionnaire was adapted from previous studies. ${ }^{(38)}$ Part A of the second questionnaire collected data on sociodemographic and socio-economic characteristics of study while part B collected data on knowledge and attitude of the study participants. A data abstraction 
sheet was used to collected specific data from patient's sick sheet. Focused Group Discussions (FGD) and Key Informant Interviews (KII) guides were used to collect qualitative data. Audio-taping was done using a phone recorder. Data collection tools were pretested by piloting $10 \%$ of the questions to 38 respondents drawn from a CCC different from the selected. The CASE Adherence Index questionnaire is known to have strong validity and reliability levels. ${ }^{(38)}$

Three FGDs were constituted classified into male, female and adolescents. Each FGD consisted of 8 participants recruited by convenience sampling technique; thus forming a total of 24 participants. Qualitative data was obtained guided by data saturation. Discussions were held in Kiswahili with translations into Kiswahili where necessary and transcribed verbatim into English.

\section{Statistical analysis}

Data was cleaned and checked for consistencies and completeness.

Data was analysed by Statistical Package for Social Sciences (SPSS) version 20. We examined the associations of the dependent and independent variables using Pearson's Chi-square statistics and logistic regression with level of significance set at $\mathrm{p}<0.05$.

Each response on knowledge was assigned a similar score (1) and calculated as: Poor $<25 \%$ - (no correct answer); moderately low (25-49\%) - 1 correct answer out of the three questions; moderately high $(50-74 \%)-2$ correct answers out of the three questions; excellent (75-100\%)- all correct answers. A respondent scoring above $50 \%$ and above was considered to have adequate knowledge on adherence to ARVS.

Each response on attitude was assigned a similar score (1) and calculated as: Poor/Good (25 - <75\%) - (no or 1 correct answer out of the two questions); Excellent (75 - 100\%)-all correct answers out of the two questions. A respondent scoring above $75 \%$ and above was considered to have positive attitude towards adherence to ARVS.

Qualitative data from was analysed by Computer-assisted qualitative data analysis software (CAQDAS) software based on thematic and core codes and conclusions drawn.

Only study subjects who had been adequately informed and voluntarily consented to participate were recruited. The study involved participants less than 18 years; thus an assent form was provided to these participants. Ethical clearance was obtained from Kenyatta National Hospital Ethics and Review Committee before implementation (Ref: KNH-ERC/A/322).

\section{RESULT}

Table 2. Socio-demographic and socio-economic characteristics of study respondents.

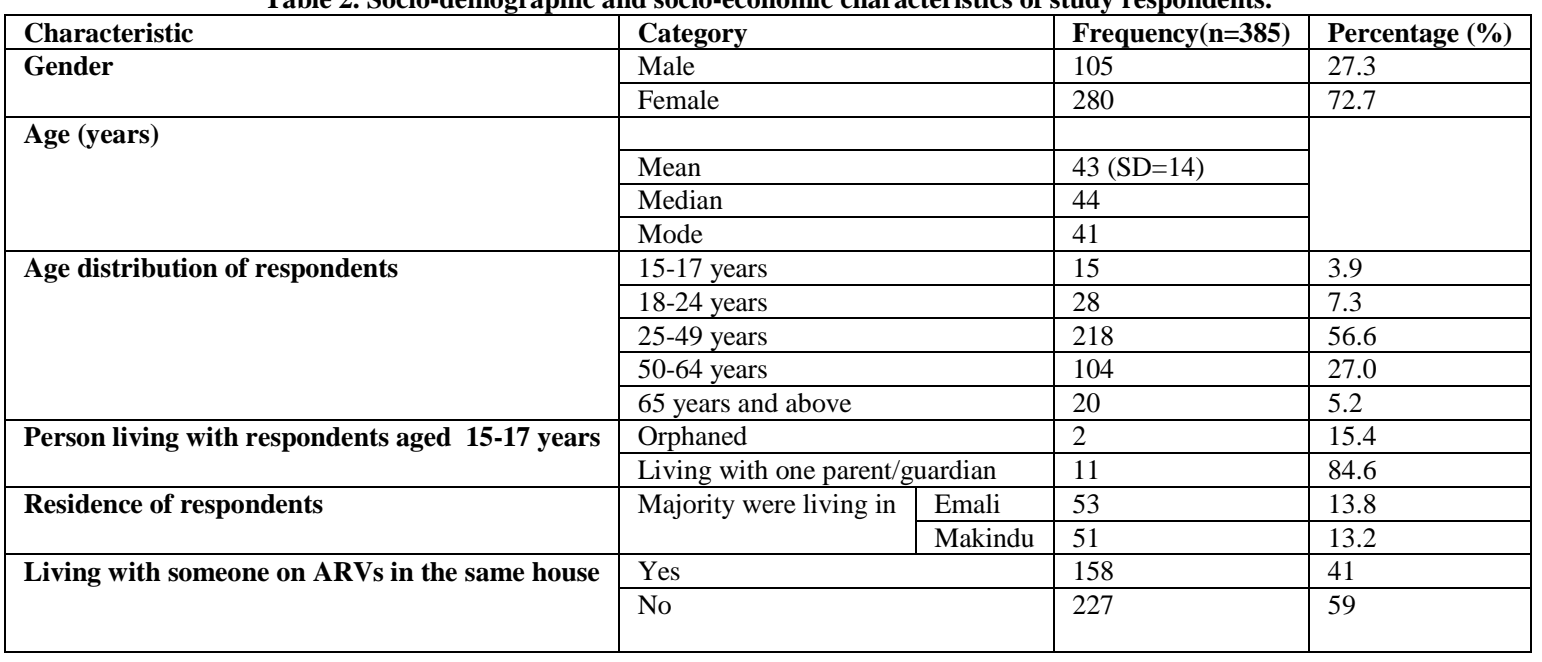


Martin Owuor Ochieng et.al. Factors associated with adherence to antiretroviral drugs among HIV positive patients attending selected comprehensive care centers in semi-urban, Kenya.

\begin{tabular}{|c|c|c|c|}
\hline \multicolumn{4}{|c|}{ Table 2 Continued... } \\
\hline \multirow[t]{7}{*}{ Marital status } & Single & 92 & 23.9 \\
\hline & Cohabiting & 22 & 5.7 \\
\hline & Married to one partner & 148 & 38.4 \\
\hline & Married to more than one partner & 2 & 0.5 \\
\hline & Divorced or separated & 47 & 12.2 \\
\hline & Widow or widower & 69 & 17.9 \\
\hline & Not applicable & 5 & 1.3 \\
\hline \multirow[t]{4}{*}{ Highest level of Education } & Never been to school & 64 & 16.6 \\
\hline & Primary & 212 & 55.1 \\
\hline & Secondary & 84 & 21.8 \\
\hline & Tertiary (college, university) & 25 & 6.5 \\
\hline \multirow[t]{4}{*}{ Occupation } & Government employee & 11 & 2.9 \\
\hline & Unemployed & 126 & 32.7 \\
\hline & Business/Self employed & 167 & 43.4 \\
\hline & Casual labourer & 81 & 21 \\
\hline \multirow[t]{7}{*}{ Monthly income } & $<\mathrm{ksh} 1000$ & 6 & 1.6 \\
\hline & ksh.1001-5000 & 31 & 8.1 \\
\hline & ksh5001-10000 & 20 & 5.2 \\
\hline & $>$ ksh 10000 & 25 & 6.5 \\
\hline & Not willing to disclose & 147 & 38.2 \\
\hline & Not sure & 50 & 13 \\
\hline & Not applicable & 106 & 27.5 \\
\hline
\end{tabular}

Table 3. Knowledge on adherence to ARVs of the respondents.

\begin{tabular}{|c|c|c|c|}
\hline Knowledge Variables & Category & Frequency $(n=385)$ & Percentage $(\%)$ \\
\hline \multirow{4}{*}{$\begin{array}{l}\text { Adherence to ARVs } \text { reduces progression } \\
\text { towards AIDS }\end{array}$} & Strongly agree & 344 & 89 \\
\hline & Agree & 39 & 10.1 \\
\hline & Disagree & 1 & 0.3 \\
\hline & Strongly disagree & 1 & 0.3 \\
\hline \multirow{4}{*}{$\begin{array}{l}\text { Adherence to ARVs reduces chances of dying } \\
\text { from HIV and its related complications }\end{array}$} & Strongly agree & 321 & 83.4 \\
\hline & Agree & 62 & 16.1 \\
\hline & Disagree & 0 & 0 \\
\hline & Strongly disagree & 2 & 0.5 \\
\hline \multirow{4}{*}{ Frequency of taking ARVs } & Once and that's all & 2 & 0.5 \\
\hline & Daily & 383 & 99.5 \\
\hline & Once in a week & 0 & 0 \\
\hline & Occasionally when one feels like & 0 & 0 \\
\hline \multirow{4}{*}{$\begin{array}{l}\text { \% Overall score on knowledge on adherence to } \\
\text { ARVs }\end{array}$} & Poor $(<25 \%)$ & 2 & 0.4 \\
\hline & Moderately low $(25-49 \%)$ & 0 & 0.1 \\
\hline & Moderately high $(50-74 \%)$ & 34 & 8.7 \\
\hline & Excellent $(75-100 \%)$ & 349 & 90.6 \\
\hline \multirow{2}{*}{$\begin{array}{l}\text { Overall score on knowledge on adherence to } \\
\text { ARVs }\end{array}$} & Adequate (Moderately high+ Excellent) & 383 & 99.3 \\
\hline & Inadequate (Poor + Moderately low) & 2 & 0.5 \\
\hline
\end{tabular}

Table 4. Attitude towards adherence to ARVs of the respondents.

\begin{tabular}{|c|c|c|c|}
\hline Attitude Variables & Category & Frequency $(n=385)$ & Percentage $(\%)$ \\
\hline \multirow{4}{*}{$\begin{array}{l}\text { ARVs are the mainstay in keeping individuals living with } \\
\text { HIV free from frequent attacks of diseases }\end{array}$} & Strongly agree & 304 & 79 \\
\hline & Agree & 78 & 20.3 \\
\hline & Disagree & 2 & 0.5 \\
\hline & Strongly disagree & 1 & 0.3 \\
\hline \multirow[t]{4}{*}{ One does not need to take ARVs as long as he/she eats well } & Strongly agree & 25 & 6.5 \\
\hline & Agree & 1 & 0.3 \\
\hline & Disagree & 70 & 17.9 \\
\hline & Strongly disagree & 289 & 74.8 \\
\hline \multirow[t]{2}{*}{ \% Overall score on attitude towards adherence to ARVs } & Poor/Good $(25-<75 \%)$ & 24 & 6.2 \\
\hline & Excellent $(75-100 \%)$ & 361 & 93.8 \\
\hline \multirow[t]{2}{*}{ Overall assessment on attitude towards adherence to ARVs } & Positive & 361 & 93.8 \\
\hline & Negative & 24 & 6.2 \\
\hline
\end{tabular}


Martin Owuor Ochieng et.al. Factors associated with adherence to antiretroviral drugs among HIV positive patients attending selected comprehensive care centers in semi-urban, Kenya.
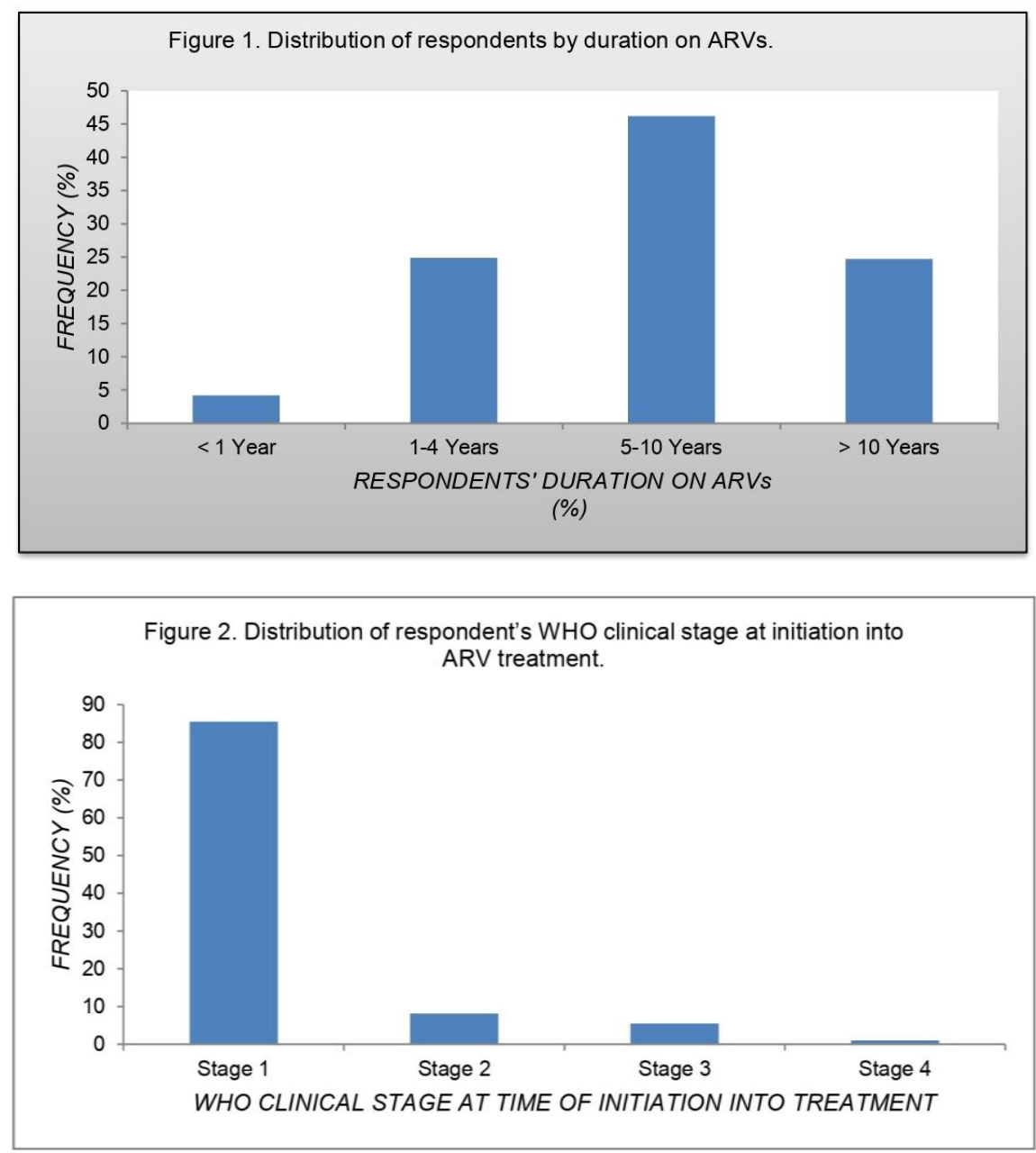

\begin{tabular}{|c|c|c|c|c|c|c|}
\hline \multirow[t]{3}{*}{ Variable } & \multirow[t]{3}{*}{ Category } & \multicolumn{4}{|c|}{$\begin{array}{l}\text { WHO clinical stage at time of } \square \text { initiation into } \\
\text { ARV }\end{array}$} & \multirow[t]{2}{*}{$\begin{array}{l}\text { Total } \\
\text { n(\%) }\end{array}$} \\
\hline & & Stage 1 & Stage 2 & Stage 3 & Stage 4 & \\
\hline & & \multicolumn{4}{|c|}{ Frequency n (\%) } & \\
\hline \multirow[t]{2}{*}{ Gender } & Male & $89(27.1)$ & $7(22.6)$ & $8(38.1)$ & $1(25)$ & $105(27.3)$ \\
\hline & Female & $240(72.9)$ & $24(77.4)$ & 13(61.9) & $3(75)$ & $280(72.7)$ \\
\hline \multirow[t]{5}{*}{ Age } & $15-17$ years & $12(3.6)$ & $3(9.7)$ & $0(0)$ & $0(0)$ & $15(3.9)$ \\
\hline & $18-24$ years & $24(7.3)$ & $3(9.7)$ & $1(4.8)$ & $0(0)$ & $28(7.3)$ \\
\hline & $25-49$ years & $187(56.8)$ & $17(54.8)$ & $11(52.4)$ & $3(75)$ & $218(56.6)$ \\
\hline & $50-64$ years & $87(26.4)$ & $7(22.6)$ & $9(42.9)$ & $1(25)$ & 104(27) \\
\hline & 65 years and above & $19(5.8)$ & $1(3.2)$ & $0(0)$ & $0(0)$ & $20(5.2)$ \\
\hline \multirow[t]{2}{*}{ 15-17 years } & Orphaned & $2(18.2)$ & $0(0)$ & $0(0)$ & $0(0)$ & $2(15.4)$ \\
\hline & $\begin{array}{l}\text { Living with one parent/ } \\
\text { guardian }\end{array}$ & 9(81.8) & $2(100)$ & $0(0)$ & $0(0)$ & $11(84.6)$ \\
\hline $\begin{array}{l}\text { Living with someone on ARVs in the } \\
\text { same house }\end{array}$ & $\begin{array}{l}\text { Yes } \\
\text { No }\end{array}$ & $\begin{array}{l}140(42.6) \\
\mathbf{1 8 9 ( 5 7 . 4 )}\end{array}$ & $\begin{array}{l}13(41.9) \\
18(58.1)\end{array}$ & $\begin{array}{l}4(19.0) \\
17(81.0)\end{array}$ & $\begin{array}{l}1(25) \\
3(75)\end{array}$ & $\begin{array}{l}158(41) \\
227(59)\end{array}$ \\
\hline \multirow[t]{7}{*}{ Marital status } & Single & $71(21.6)$ & $16(51.6)$ & $4(19)$ & $1(25)$ & $92(23.9)$ \\
\hline & Cohabiting & $21(6.4)$ & $0(0)$ & $0(0)$ & $1(25)$ & $22(5.7)$ \\
\hline & Married to one partner & $133(40.4)$ & $9(29)$ & $6(28.6)$ & $0(0)$ & $148(38.4)$ \\
\hline & $\begin{array}{l}\text { Married to more than one } \\
\text { partner }\end{array}$ & $2(0.6)$ & $0(0)$ & $0(0)$ & $0(0)$ & $2(0.5)$ \\
\hline & Divorced or separated & $34(10.3)$ & $3(9.7)$ & $8(38.1)$ & $2(50)$ & $47(12.2)$ \\
\hline & Widow or widower & $63(19.1)$ & $3(9.7)$ & $3(14.3)$ & $0(0)$ & $69(17.9)$ \\
\hline & Not applicable & $5(1.5)$ & $0(0)$ & $0(0)$ & $0(0)$ & $5(1.3)$ \\
\hline \multirow[t]{4}{*}{ Highest Level of Education } & Never been to school & $54(16.4)$ & $7(22.6)$ & $2(9.5)$ & $1(25)$ & $64(16.6)$ \\
\hline & Primary & $180(54.7)$ & $15(48.4)$ & $14(66.7)$ & $3(75)$ & $212(55.1)$ \\
\hline & Secondary & $72(21.9)$ & $8(25.8)$ & $4(19)$ & $0(0)$ & $84(21.8)$ \\
\hline & Tertiary (college, university) & $23(7)$ & $1(3.2)$ & $1(4.8)$ & $0(0)$ & $25(6.5)$ \\
\hline \multirow[t]{4}{*}{ Occupation } & Government employee & $11(3.3)$ & $0(0)$ & $0(0)$ & $0(0)$ & 11(2.9) \\
\hline & Unemployed & $109(33.1)$ & $11(35.5)$ & $5(23.8)$ & $1(25)$ & $126(32.7)$ \\
\hline & Business/Self employed & $144(43.8)$ & $11(35.5)$ & $11(52.4)$ & $1(25)$ & $167(43.4)$ \\
\hline & Casual labourer & $65(19.8)$ & $9(29)$ & $5(23.8)$ & $2(50)$ & $81(21)$ \\
\hline
\end{tabular}


Martin Owuor Ochieng et.al. Factors associated with adherence to antiretroviral drugs among HIV positive patients attending selected comprehensive care centers in semi-urban, Kenya.

\begin{tabular}{|c|c|c|c|c|c|c|}
\hline \multicolumn{7}{|c|}{ Table 5 Continued... } \\
\hline \multirow{7}{*}{ Monthly income } & \multirow{7}{*}{$\begin{array}{l}<\mathrm{ksh} 1000 \\
\mathrm{ksh} .1001-5000 \\
\text { ksh5001-10000 } \\
>\text { ksh } 10000 \\
\text { Not willing to disclose } \\
\text { Not sure } \\
\text { Not applicable }\end{array}$} & $5(1.5)$ & $1(3.2)$ & $0(0)$ & $0(0)$ & $6(1.6)$ \\
\hline & & $28(8.5)$ & $3(9.7)$ & $0(0)$ & $0(0)$ & $31(8.1)$ \\
\hline & & $19(5.8)$ & $1(3.2)$ & $0(0)$ & $0(0)$ & $20(5.2)$ \\
\hline & & $24(7.3)$ & $1(3.2)$ & $0(0)$ & $0(0)$ & $25(6.5)$ \\
\hline & & 114(34.7) & $14(45.2)$ & $17(81)$ & $2(50)$ & $147(38.2)$ \\
\hline & & $46(14)$ & $2(6.5)$ & $1(4.8)$ & $1(25)$ & $50(13)$ \\
\hline & & $93(28.3)$ & $9(29)$ & $3(14.3)$ & $1(25)$ & $106(27.5)$ \\
\hline
\end{tabular}
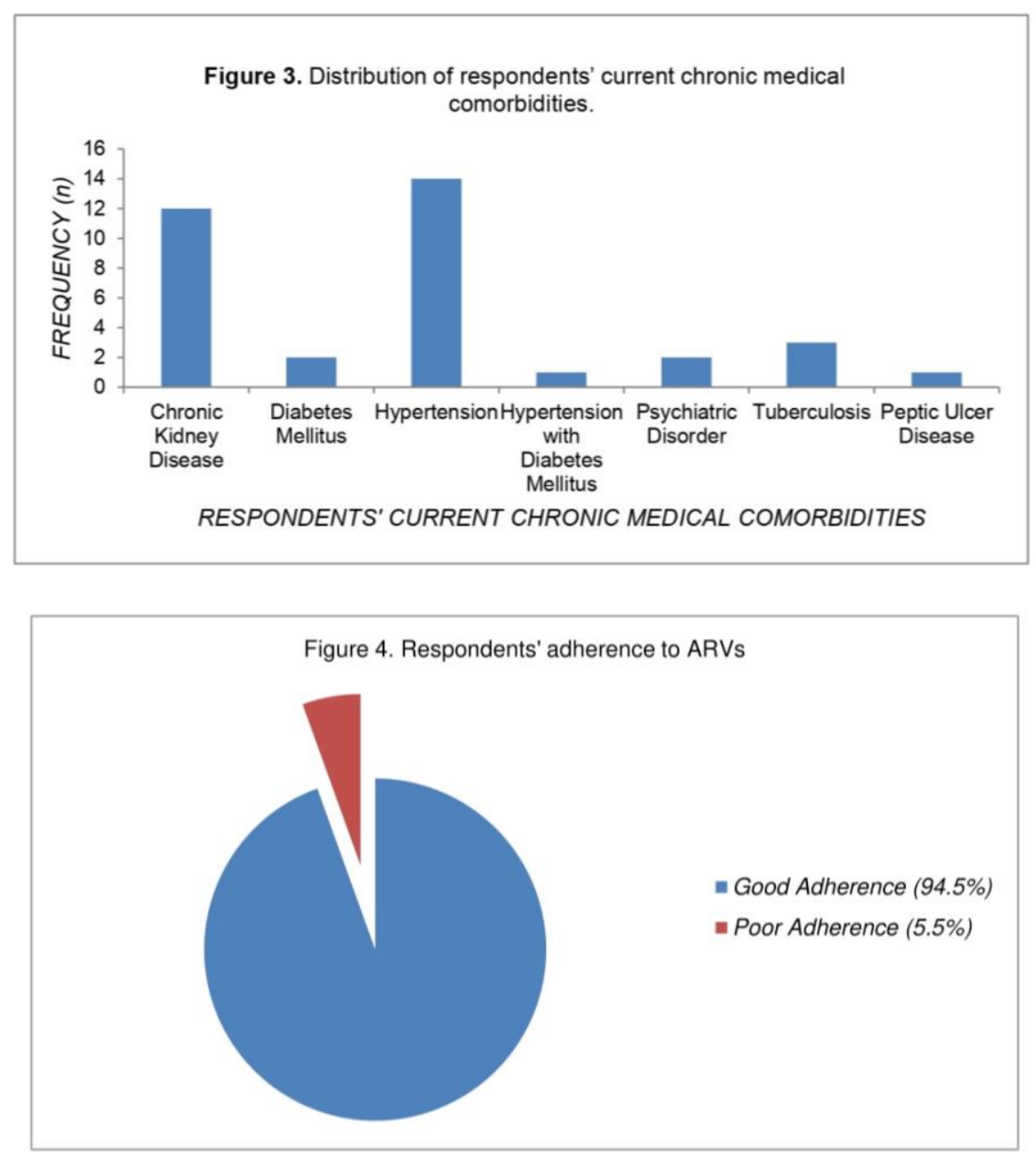

Table 6. Prevalence of adherence to ARVs adherence to ARVs against socio-economic characteristics among HIV positive patients attending selected CCCs in Kibwezi West sub-county, Makueni County, Kenya.

\begin{tabular}{|c|c|c|c|}
\hline \multirow[t]{2}{*}{ Variable } & \multirow[t]{2}{*}{ Category } & $\begin{array}{l}\begin{array}{l}\text { Adherent } \\
(n=364)\end{array} \\
\end{array}$ & $\begin{array}{l}\text { Non-adherent } \\
(\mathbf{n}=\mathbf{2 1})\end{array}$ \\
\hline & & Frequency $\mathrm{n}(\%)$ & Frequency n (\%) \\
\hline \multirow[t]{2}{*}{ Gender } & Male & $95(26.1)$ & $10(47.6)$ \\
\hline & Female & $269(73.9)$ & $11(52.4)$ \\
\hline \multirow[t]{5}{*}{ Age } & $15-17$ years & $12(3.3)$ & $3(14.3)$ \\
\hline & $18-24$ years & $24(6.6)$ & $4(19)$ \\
\hline & $25-49$ years & $207(56.9)$ & $11(52.4)$ \\
\hline & $50-64$ years & $101(27.7)$ & $3(14.3)$ \\
\hline & 65 years and above & $20(5.5)$ & $0(0)$ \\
\hline \multirow[t]{2}{*}{ 15-17 years } & Orphaned & $1(10)$ & $1(33.3)$ \\
\hline & Living with one parent/guardian & $9(90)$ & $2(66.7)$ \\
\hline Living with someone on ARVs in the same house & $\begin{array}{l}\text { Yes } \\
\text { No }\end{array}$ & $\begin{array}{l}145(39.8) \\
219(60.2)\end{array}$ & $\begin{array}{l}13(61.9) \\
8(38.1)\end{array}$ \\
\hline \multirow[t]{7}{*}{ Marital status } & Single & $87(23.9)$ & $5(23.8)$ \\
\hline & Cohabiting & $19(5.2)$ & $3(14.3)$ \\
\hline & Married to one partner & $141(38.7)$ & $7(33.3)$ \\
\hline & Married to more than one partner & $1(0.3)$ & $1(4.8)$ \\
\hline & Divorced or separated & $44(12.1)$ & $3(14.3)$ \\
\hline & Widow or widower & $68(18.7)$ & $1(4.8)$ \\
\hline & Not applicable & $4(1.1)$ & $1(4.8)$ \\
\hline
\end{tabular}


Martin Owuor Ochieng et.al. Factors associated with adherence to antiretroviral drugs among HIV positive patients attending selected comprehensive care centers in semi-urban, Kenya.

\begin{tabular}{|l|l|l|l|}
\hline \multicolumn{3}{|l}{ Table 6 Continued... } \\
\hline \multirow{4}{*}{ Highest Level of Education } & Never been to school & $60(16.5)$ & $4(19)$ \\
\cline { 2 - 4 } & Primary & $201(55.2)$ & $11(52.4)$ \\
\cline { 2 - 4 } & Secondary & $78(21.4)$ & $6(28.6)$ \\
\cline { 2 - 4 } & Tertiary (college, university) & $25(6.9)$ & $0(0)$ \\
\hline \multirow{5}{*}{ Occupation } & Government employee & $11(3)$ & $0(0)$ \\
\cline { 2 - 4 } & Unemployed & $116(31.9)$ & $10(47.6)$ \\
\cline { 2 - 4 } & Business/Self employed & $160(44)$ & $7(33.3)$ \\
\cline { 2 - 4 } & Casual labourer & $77(21.2)$ & $4(19)$ \\
\hline \multirow{4}{*}{ Monthly income } & <sh1000 & $6(1.6)$ & $0(0)$ \\
\cline { 2 - 4 } & ksh.1001-5000 & $30(8.2)$ & $1(4.8)$ \\
\cline { 2 - 4 } & ksh5001-10000 & $20(5.5)$ & $0(0)$ \\
\cline { 2 - 4 } & $>$ ksh 10000 & $24(6.6)$ & $1(4.8)$ \\
\cline { 2 - 4 } & Not willing to disclose & $140(38.5)$ & $7(33.3)$ \\
\cline { 2 - 4 } & Not sure & $47(12.9)$ & $3(14.3)$ \\
\hline Total for each variable & Not applicable & $97(26.6)$ & $9(42.9)$ \\
\hline & & $364(100)$ & $21(100)$ \\
\hline
\end{tabular}

There was a significant association between adherence to ARVs and gender $\left\{\chi^{2}\right.$ (1) $=4.636, p<0.05\}$; however, the strength of association was low (Cramer's' V 0.110). The odds of poor adherence among males was 0.174 against females (95\%CI 0.130 , 0.233). Thus, female gender was likely to adhere to ARVs than the male gender (Table 7).

Table 7. Binary logistic regression analysis of association between gender and adherence to ARVs.

\begin{tabular}{|c|c|c|c|c|c|c|c|c|c|}
\hline \multicolumn{10}{|c|}{ Variables in the Equation } \\
\hline & & \multirow[t]{2}{*}{ B } & \multirow[t]{2}{*}{ S.E. } & \multirow[t]{2}{*}{ Wald } & \multirow[t]{2}{*}{ df } & \multirow[t]{2}{*}{ Sig. } & \multirow[t]{2}{*}{$\operatorname{Exp}(\mathbf{B})$} & \multicolumn{2}{|c|}{ 95\% C.I.for EXP(B) } \\
\hline & & & & & & & & Lower & Upper \\
\hline Step $1^{\text {a }}$ & Gender & -1.749 & .149 & 138.201 & 1 & .000 & .174 & .130 & .233 \\
\hline
\end{tabular}

Age was significantly associated with adherence \{Likelihood Ratio $\mathrm{G}^{2}$ (4) $=10.693, \mathrm{p}<0.05\}$ with a low strength of association (Cramer's' V 0.183). The odds of poor adherence among respondents aged
65 years and above was 0.30 , the least among the age categories (95\%CI 0.09 , 0.094); thus more likely to adhere to ARVs (Table 8).

Table 8. Binary logistic regression analysis of association age and adherence to ARVs.

\begin{tabular}{|c|c|c|c|c|c|c|c|c|c|}
\hline \multicolumn{10}{|c|}{ Variables in the Equation } \\
\hline & & \multirow[t]{2}{*}{ B } & \multirow[t]{2}{*}{ S.E. } & \multirow[t]{2}{*}{ Wald } & \multirow[t]{2}{*}{ df } & \multirow[t]{2}{*}{ Sig. } & \multirow[t]{2}{*}{$\operatorname{Exp}(\mathbf{B})$} & \multicolumn{2}{|c|}{ 95\% C.I.for EXP(B) } \\
\hline & & & & & & & & Lower & Upper \\
\hline \multirow[t]{5}{*}{ Step $1^{a}$} & Age & & & 141.611 & 4 & .000 & & & \\
\hline & $\operatorname{Age}(1)$ & -1.386 & .645 & 4.612 & 1 & .032 & .250 & .071 & .886 \\
\hline & $\operatorname{Age}(2)$ & -1.792 & .540 & 11.007 & 1 & .001 & .167 & .058 & .480 \\
\hline & $\operatorname{Age}(3)$ & -2.935 & .309 & 89.964 & 1 & .000 & .053 & .029 & .097 \\
\hline & $\operatorname{Age}(4)$ & -3.517 & .586 & 36.027 & 1 & .000 & .030 & .009 & .094 \\
\hline
\end{tabular}

Living in the same house with someone on ARVs was significantly associated with adherence to ARVs $\left\{\chi^{2}(1)\right.$ $=3.997 \mathrm{p}=<0.05\}$ with a low strength of association (Cramer's' V 0.102). The odds of poor adherence among respondents living in the same house with someone on ARVs was 0.144 compared to those living without (95\%CI $0.103,0.200)$; thus, more likely to adhere to ARVs (Table 9).

Table 9. Binary logistic regression analysis of association between living with someone on ARVs in the same house and adherence to ARVs.

\begin{tabular}{|l|l|l|l|l|l|l|l|l|l|}
\hline Variables in the Equation & B & S.E. & Wald & df & Sig. & Exp(B) & \multicolumn{2}{|c|}{ 5\% C.I.for EXP(B) } \\
& & & & & & & Lower & Upper \\
\hline Step 1 & Living with someone on ARVs in the same house & -1.941 & .168 & 133.028 & 1 & .000 & .144 & .103 & .200 \\
\hline Variable(s) entered on step 1: Living with someone on ARVs in the same house. \\
\hline
\end{tabular}


Martin Owuor Ochieng et.al. Factors associated with adherence to antiretroviral drugs among HIV positive patients attending selected comprehensive care centers in semi-urban, Kenya.

Table 10. Socio-demographic and economic factors associated with adherence to ARVs among HIV positive patients attending selected CCCs in Kibwezi West sub-county, Makueni County, Kenya.

\begin{tabular}{|c|c|c|c|c|}
\hline \multirow{3}{*}{$\begin{array}{ll}\begin{array}{l}\text { Socio-demographic } \\
\text { economic characteristic }\end{array} & \text { and } \\
\text { Gender } & \end{array}$} & \multirow[t]{2}{*}{ Category } & \multicolumn{2}{|c|}{$\begin{array}{l}\text { Adherence level } \\
(\mathrm{n}=385)\end{array}$} & \multirow[t]{2}{*}{$\begin{array}{l}\text { Chi Square test of significance Level } \\
\text { of significance }=p<0.05\end{array}$} \\
\hline & & $\begin{array}{l}\text { Adherent } \\
\mathrm{n}=364\end{array}$ & $\begin{array}{l}\text { Not adherent } \\
n=21\end{array}$ & \\
\hline & $\begin{array}{l}\text { Male } \\
\text { Female }\end{array}$ & $\begin{array}{l}95(26.1 \%) \\
269(73.9 \%)\end{array}$ & $\begin{array}{l}10(47.6 \%) \\
11(54.6 \%) \\
\end{array}$ & $\begin{array}{l}\chi^{2}(1)=4.636 \\
P=0.031\end{array}$ \\
\hline \multirow[t]{5}{*}{ Age } & $15-17$ years & $12(3.3 \%)$ & $3(14.8 \%)$ & \multirow{5}{*}{$\begin{array}{l}G^{2}(4)=10.693 \\
P=0.030\end{array}$} \\
\hline & $18-24$ years & $24(6.6 \%)$ & $4(19 \%)$ & \\
\hline & $25-49$ years & $207(56.9 \%)$ & $11(52.4 \%)$ & \\
\hline & $50-64$ years & $101(27.7 \%)$ & $3(14.3 \%)$ & \\
\hline & 65 years and above & $20(5.5 \%)$ & $0(0 \%)$ & \\
\hline \multirow[t]{3}{*}{ Ages 15-17 years } & & $\begin{array}{l}\text { Adherent } \\
\mathrm{n}=10\end{array}$ & $\begin{array}{l}\text { Not adherent } \\
n=3\end{array}$ & \\
\hline & Orphaned & $1(10 \%)$ & $1(33.3 \%)$ & \multirow{2}{*}{$\begin{array}{l}\mathrm{G}^{2}(1)=0.842 \\
\mathrm{P}=0.359\end{array}$} \\
\hline & $\begin{array}{l}\text { Living with one } \\
\text { parent/guardian }\end{array}$ & $9(90 \%)$ & $2(66.7 \%)$ & \\
\hline \multirow[t]{3}{*}{$\begin{array}{l}\text { Living with someone on ARVs } \\
\text { in the same house }\end{array}$} & & $\begin{array}{l}\text { Adherent } \\
\mathrm{n}=364\end{array}$ & $\begin{array}{l}\text { Not adherent } \\
n=21\end{array}$ & \\
\hline & Yes & $145(39.8 \%)$ & $13(61.9 \%)$ & \multirow{2}{*}{$\begin{array}{l}\chi^{2}(1)=3.997 \\
P=0.046\end{array}$} \\
\hline & No & $219(60.2 \%)$ & $8(38.1 \%)$ & \\
\hline \multirow[t]{8}{*}{ Marital status } & & $\begin{array}{l}\text { Adherent } \\
\mathrm{n}=364\end{array}$ & $\begin{array}{l}\text { Not adherent } \\
n=21\end{array}$ & \\
\hline & Single & $87(23.9 \%)$ & $5(23.8 \%)$ & \multirow{7}{*}{$\begin{array}{l}\mathrm{G}^{2}(6)=9.702 \\
\mathrm{P}=0.138\end{array}$} \\
\hline & Cohabiting & $19(5.2 \%)$ & $3(14.3 \%)$ & \\
\hline & Married to one partner & $141(38.7 \%)$ & $7(33.3 \%)$ & \\
\hline & $\begin{array}{l}\text { Married to more than } \\
\text { one partner }\end{array}$ & $1(0.3 \%)$ & $1(4.8 \%)$ & \\
\hline & Divorced or separated & $44(12.1 \%)$ & $3(14.3 \%)$ & \\
\hline & Widow or widower & $68(18.7 \%)$ & $1(4.8 \%)$ & \\
\hline & Not applicable & $4(1.1 \%)$ & $1(4.8 \%)$ & \\
\hline \multirow[t]{5}{*}{ Highest education level } & & $\begin{array}{l}\text { Adherent } \\
\mathrm{n}=364\end{array}$ & $\begin{array}{l}\text { Not adherent } \\
n=21\end{array}$ & \multirow[t]{5}{*}{$\begin{array}{l}\mathrm{G}^{2}(3)=3.334 \\
\mathrm{P}=0.343\end{array}$} \\
\hline & Never been to school & $60(16.5 \%)$ & $4(19 \%)$ & \\
\hline & Primary & $201(55.2 \%)$ & $11(52.4 \%)$ & \\
\hline & Secondary & $78(21.4 \%)$ & $6(28.6 \%)$ & \\
\hline & $\begin{array}{ll}\begin{array}{l}\text { Tertiary } \\
\text { university) }\end{array} & \text { (college, } \\
\end{array}$ & $25(6.9 \%)$ & $0(0.0 \%)$ & \\
\hline \multirow[t]{5}{*}{ Occupation } & & $\begin{array}{l}\text { Adherent } \\
\mathrm{n}=364\end{array}$ & $\begin{array}{l}\text { Not adherent } \\
\mathrm{n}=21\end{array}$ & \multirow[t]{5}{*}{$\begin{array}{l}\mathrm{G}^{2}(3)=3.165 \\
\mathrm{P}=0.367\end{array}$} \\
\hline & Government employee & $11(3.0 \%)$ & $0(0.0 \%)$ & \\
\hline & Unemployed & $116(31.9 \%)$ & $10(47.6 \%)$ & \\
\hline & Business/Self employed & $160(44 \%)$ & $7(33.3 \%)$ & \\
\hline & Casual labourer & $77(21.2 \%)$ & $4(19 \%)$ & \\
\hline \multirow[t]{8}{*}{ Monthly income } & & $\begin{array}{l}\text { Adherent } \\
\mathrm{n}=364\end{array}$ & $\begin{array}{l}\text { Not adherent } \\
n=21\end{array}$ & \multirow[t]{8}{*}{$\begin{array}{l}\mathrm{G}^{2}(6)=5.180 \\
\mathrm{P}=0.521\end{array}$} \\
\hline & $\begin{array}{l}\mathrm{ksh} 1000 \\
\end{array}$ & $6(1.6 \%)$ & $0(0.0 \%)$ & \\
\hline & ksh.1001-5000 & $30(8.2 \%)$ & $1(4.8 \%)$ & \\
\hline & ksh5001-10000 & $20(5.5 \%)$ & $0(0.0 \%)$ & \\
\hline & $>$ ksh 10000 & $24(6.6 \%)$ & $1(4.8 \%)$ & \\
\hline & Not willing to disclose & $140(38.5 \%)$ & $7(33.3 \%)$ & \\
\hline & Not sure & $47(12.9 \%)$ & $3(14.3 \%)$ & \\
\hline & Not applicable & $97(26.6 \%)$ & $9(42.9 \%)$ & \\
\hline
\end{tabular}

Table 11. Behavioural factors associated with adherence to ARVs among HIV positive patients attending selected CCCs in Kibwezi West sub-county, Makueni County, Kenya.

\begin{tabular}{|c|c|c|c|c|}
\hline Behavioural factors & Category & $\begin{array}{l}\text { Adherence l } \\
(\mathrm{n}=\mathbf{3 8 5})\end{array}$ & & $\begin{array}{l}\text { Chi Square test of significance Level of } \\
\text { significance }=p<0.05\end{array}$ \\
\hline \multirow[t]{2}{*}{$\begin{array}{l}\text { Knowledge on adherence to } \\
\text { ARVs }\end{array}$} & & $\begin{array}{l}\text { Adherent } \\
\mathrm{n}=364\end{array}$ & $\begin{array}{l}\text { Not } \text { adherent } \\
\mathbf{n = 2 1}\end{array}$ & \\
\hline & $\begin{array}{l}\text { Adequate } \\
\text { Inadequate }\end{array}$ & $\begin{array}{l}362(99.5 \%) \\
2(0.5 \%)\end{array}$ & $\begin{array}{l}21(100 \%) \\
0(0 \%)\end{array}$ & $\mathrm{G}^{2}(1)=0.225, \mathrm{P}=0.635$ \\
\hline \multirow{2}{*}{$\begin{array}{l}\text { Attitude towards adherence to } \\
\text { ARVs }\end{array}$} & Positive & $340(93.4 \%)$ & $21(100 \%)$ & \multirow[t]{2}{*}{$\mathrm{G}^{2}(1)=2.782, \mathrm{P}=0.095$} \\
\hline & Negative & $24(6.6 \%)$ & $0(0 \%)$ & \\
\hline
\end{tabular}

The quantitative results were collaboration by FGD results in which the Male focus group discussion identified fear, stigma, not believing in oneself, participating in activities that hamper adherence such as drinking alcohol and denial as the main causes of poor adherence to ARVs. Discussant number 3 observed, 
'The first thing contributing to not taking these drugs is hiding. Second is fear". The discussion also identified increase in frequency and severity of opportunistic diseases, increased viral load, reduced immunity, family-social consequences and ultimately death as consequences of poor adherence to ARVs. Discussant number 5 said, "Most of the diseases would just find it very to come to your body and they make you very weak and even you can...can lead to death" Nevertheless, the group identified one-on-one educational counselling sessions, seeking advice, group education with similar infected people and social support as means to improve adherence to ARVs. Discussant number 8 suggested, "It is through ways of counselling through doctors or group counselling."

The Female focus group discussion identified religious beliefs, denial and lack of self-love as the main reasons of poor adherence to ARVs. Discussant number 2 averred, "One must accept oneself and love self to be able to take drugs well." The group also identified increase in severity of opportunistic infections and frequent hospitalisation as the main consequences of poor adherence to ARVs. Discussant number 4 posited, "If you fail to take the drugs because it is your responsibility, you will keep visiting the hospital with pain here, pain there." Nonetheless, it identified adherence counselling support by health workers, acceptance of one's status, social and family support as means to improve adherence to ARVs. Participant number 9 suggested, "To improve adherence, one must accept of the eternity of ARVs early enough until God's appointed time." Adolescent focus group discussion identified defiance, stigma, and ignorance on reasons for medication, fear and denial as reasons for poor adherence to ARVs. Discussant number 4 noted, "One may have not been told why they are taking the drugs." The group also identified increased frequency of diseases, hospitalisations, morbidity and death as the consequences of poor adherence to ARVs. Participant number 5 observed, "When you fail to take medications well, viral load goes up." However, the group noted that knowing one's status, acceptance, personal discipline on adherence and reminders such clock alarms or a trusted person are ways to improve adherence to ARVs. Discussant number 8 suggested "You have to understand that life does not end with getting HIV/AIDS, so you have to continue taking medications well not to get diseases frequently."

Table 12. Clinical factors associated with Adherence to ARVs among HIV positive patients attending selected CCCs in Kibwezi West sub-county, Makueni County, Kenya.

\begin{tabular}{|c|c|c|c|c|}
\hline Clinical parameter & Category & \multicolumn{2}{|l|}{$\begin{array}{l}\text { Adherence level } \\
(\mathrm{n}=385)\end{array}$} & $\begin{array}{l}\text { Chi Square test of } \\
\text { significance Level of }\end{array}$ \\
\hline \multirow{5}{*}{$\begin{array}{l}\text { WHO Clinical Stage at } \\
\text { the Time of Initiation } \\
\text { into Treatment }\end{array}$} & & Adherent $n=364$ & Not adherent $n=21$ & \\
\hline & Stage 1 & $314(86.3 \%)$ & $15(71.4 \%)$ & \multirow{4}{*}{$\begin{array}{l}\mathrm{G}^{2}(3)=3.364 \\
\mathrm{P}=0.304\end{array}$} \\
\hline & Stage 2 & $28(7.7 \%)$ & $3(14.3 \%)$ & \\
\hline & Stage 3 & $19(5.2 \%)$ & $3(9.5 \%)$ & \\
\hline & Stage 4 & $3(0.8 \%)$ & $1(4.8 \%)$ & \\
\hline \multirow{9}{*}{$\begin{array}{lr}\text { Current } & \text { chronic } \\
\text { medical co-morbidities }\end{array}$} & & Adherent $n=364$ & Not adherent $\mathrm{n}=\mathbf{2 1}$ & \\
\hline & Chronic Kidney Disease & $12(3.3 \%)$ & $0(0.0 \%)$ & \multirow{8}{*}{$\begin{array}{l}\mathrm{G}^{2}(7)=4.122 \\
\mathrm{P}=0.766\end{array}$} \\
\hline & Diabetes Mellitus & $2(0.5 \%)$ & $0(0.0 \%)$ & \\
\hline & Hypertension & $14(3.8 \%)$ & $0(0.0 \%)$ & \\
\hline & $\begin{array}{l}\text { Hypertension with Diabetes } \\
\text { Mellitus }\end{array}$ & $1(0.3 \%)$ & $0(0.0 \%)$ & \\
\hline & None & $329(90.4 \%)$ & $21(100 \%)$ & \\
\hline & Psychiatric Disorder & $2(0.5 \%)$ & $0(0.0 \%)$ & \\
\hline & Tuberculosis & $3(0.8 \%)$ & $0(0.0 \%)$ & \\
\hline & Peptic Ulcer Disease & $1(0.3 \%)$ & $0(0.0 \%)$ & \\
\hline \multirow[t]{5}{*}{ Duration on ARVs } & & Adherent $n=364$ & Not adherent $\mathrm{n}=\mathbf{2 1}$ & \multirow{5}{*}{$\begin{array}{l}\mathrm{G}^{2}(3)=0.194 \\
\mathrm{P}=0.978\end{array}$} \\
\hline & $<1$ year & $15(4.1 \%)$ & $1(4.8 \%)$ & \\
\hline & $1-4$ years & $90(24.7 \%)$ & $6(28.6 \%)$ & \\
\hline & $5-10$ years & $169(46.4 \%)$ & $9(42.9 \%)$ & \\
\hline & $>10$ years & $90(24.7 \%)$ & $5(23.8 \%)$ & \\
\hline
\end{tabular}



patients attending selected comprehensive care centers in semi-urban, Kenya.

Two key informants (the in-charges involved in primary care of HIV positive patients) from respective CCCs were interviewed. They identified stigma, ignorance, lack of social support and busy work schedule as patient level factors that would hamper adherence to ARVs. KIIs identified poor attitude by health service providers, drug stock outs, distance, and long waiting time contributing to poor adherence to ARVs. On how to improve adherence to ARVs, they identified community dispensing, health talks with mentors, support groups, drug availability, outreach, psychosocial support, distribution of patients to nearest satellite clinics, encourage disclosure and directly observed therapy (DOT) by a trusted relative. KI number 1 suggested, "I think the major thing is stigma. If stigma was done away with, then everything will run off smooth."

\section{DISCUSSION}

Approximately ninety five percent $(94.5 \%)$ of the respondents were adherent to ARVs. This portends good progress in reaching the target UNAIDS goal of 90-9090 by $2020,{ }^{(39)}$ Makueni County Strategic Direction 4.4.2 in the Makueni County HIV, Aids, and Tb Strategic Plan 2015/162018/19 ${ }^{(40)}$ as well as Kenya Aids Strategic Framework (KASF) priority intervention areas. ${ }^{(41)}$ This could be attributed to the 'test-and-treat all' approachn Africa. The findings contrast with a systematic review in Sub-Sahara Africa that shows an adherence estimate of $72.9 \% \%$ to ARVs. ${ }^{(2)}$ The results; however, concur with a recently conducted laboratory-based study on Kenyans aged 18-64 years that indicate less than $10 \%$ of Kenyans are not adhering to ARVs. ${ }^{(13)}$ In as much as the results are not generalizable as the study was conducted in Kenya's capital city, the concurrence is worth appreciating. The high prevalence of good adherence in key population areas serves as a control point in halting the spread of the virus.

Gender was significantly associated with adherence to ARVs. Majority of those adherents were females 269(73.9\%) showing that females were more likely to adhere to ARVs than their male counterparts. This differs from a recent study done in Sub-Saharan Africa that show females were more likely to have poor adherence to ARVs than males. ${ }^{(11)}$ It also differs with a recent Malawian study that did not find any assocaition between gender and adherence to ARVs. ${ }^{(17)}$ Females have better health-seeking behaviour thus are more likely to adhere to their medication. Besides, more women are infected thus conversely more are enrolled into care and treatment therefore more numbers of adherents.

Age was significantly associated with adherence in the sense that older age (above 65 years) was more likely to adhere to ARVs. This concurs with most studies in sub-Saharan Africa that shows poor adherence among the younger ages. ${ }^{(7,}, 15,16$, 18) This is presumed to be due to better understanding of the importance of drug adherence in prolonging life to meet their family and societal obligations. Younger population who is the country's economic driver is at an increased risk of poor adherence.

Among respondents aged 15-17 years, being orphaned or living with one parent/guardian did not have a significant association with adherence to ARVs. This differs from studies that show good adherence among persons with social support systems. ${ }^{(9,12,14)}$ Similarly, marital status did not have a statistically significant association with adherence to ARVs; differing with studies that show good adherence among individuals with social capital. ${ }^{(9,14)}$ Marriage in itself is not a predictor of better adherence to medication but perhaps mutual support and understanding within a marriage setup would improve adherence to ARVs.

Living in the same house with someone on ARVs was significantly associated with adherence to ARVs. This concurs with studies that show good adherence among individuals with social 
capital. ${ }^{(9,12,14)}$ Social support in high stigma related HIV environment is important in enhancing adherence to ARVs. Education level and occupation did not have a statistically significant association with adherence to ARVs. This differs with a recent Tanzanian study that shows poor adherence rates among individuals who are unemployed and who attained tertiary education. (16) Education level and type of occupation may not have much bearing on adherence to medication if it does not influence attitude. There is a difference between attaining an education and being educated to influence behaviour change. Results from the study shows no significant association between monthly income and adherence to ARVs which differs from other studies that show association between high asset index and adherence to ARVs . ${ }^{(18,20)}$ However, the finding is in concordance with a recent Congo study that shows no association between adherence and incentives. (21) In as much as money is necessary in meeting basic needs and to some extend make access and consequently adherence to medication easier, it may also overshadow behaviour change towards adherence.

There was no significant association between neither knowledge nor attitude towards adherence to ARVs and adherence to ARVs. Findings from the study differ with a systematic review of Sub-Saharan Africa that knowledge about HIV status was associated with better adherence. ${ }^{(8)}$ Other studies conducted in South Africa, Zambia, Uganda and Tanzania avers that there was a positive association between adherence to ARVs and knowledge on HIV and ARV in contrast to findings from the study. (29-32) Knowledge and attitude are abstract. Adherence to medication is practical. Thus, one may have the correct knowledge and the right attitude towards adhering to ARVs but fails to take the initiative to actually adhere to the medications probably influenced by other factors.

There was no statistically significant association between duration on ARVs and adherence to ARVs. It differs from a Kenyan study done in Nyeri that showed interruption of treatment among individuals who had been on ARVs for longer duration. (19) This could be attributed to treatment fatigue and other compounding factors.

There was no statistically significant association between WHO clinical stage at the time of initiation into treatment and adherence to ARVs. Most studies have not related WHO clinical stage at ART initiation and adherence; however, a recent study in Uganda indicates that baseline WHO clinical stage 1 and 2 were associated with viral suppression, ${ }^{(25)}$ a proxy indicator of adherence. However, adherence to ARVs is measured on a long term basis and given the life-time nature of ARV treatment, WHO clinical stage at time of entry into care may not impact adherence thereafter.

There was no statistically significant association between current chronic medical co-morbidities and adherence to ARVs. The findings differ with recent African studies that show poor adherence and treatment failure among patients on treatment for psychological disorder, ${ }^{(26)}$ and tuberculosis ${ }^{(23)}$ respectively.

KIIs identified stigma, busy work schedule, poor attitude by health service providers, drug stock outs, distance and long waiting time as facility level factors contributing to poor adherence to ARVs. This compares to two studies in SubSaharan Africa that identified HIV-related stigma, work-related demand, drug-related side effects and human resource-related factors hampering adherence to ARVs. ${ }^{(9,11 \text {, }}$ 12) Stigma is mostly associated with HIV being a 'behavioural' problem thus people are presumed to be responsible for their HIV status. Kibwezi West Sub-County being a semi-arid area, most residents are busy in various economic activities to sustain themselves or their dependants thus may miss out on their clinic appointments.

\section{Limitation}

It was a planting season, thus the turnout was poor. $\mathrm{K}^{\text {th }}$ value had to be 
statistically adjusted based on the average turnout per day. Only 3 FGDs- male, female and adolescents were conducted. Stratification based on education level was not possible as it was a planting season thus most prioritized farming citing no time thus no quorum.

\section{CONCLUSION}

The near optimal adherence level to ARVs in Kibwezi-West Sub County is comparable with the WHO recommended level of $95 \%$. This portends good progress in the fight against the HIV scourge. Majority of respondents had adequate knowledge and positive attitude towards adherence to ARVs. Being of female gender, older age (above 65 years) and sharing a roof with someone on ARVs predicted better adherence.

Conflict of Interest Declaration: There is no conflict of interest.

\section{ACKNOWLEDGEMENT}

Sincere gratitude goes to my supervisors Prof. Gideon Kikuvi and Dr. Daniel Mokaya for their invaluable advice, support, mentorship, and input throughout proposal development and drafting this thesis. Their untiring selves and availability whenever I needed advice cannot go unnoticed. Their critique was essential in refining this piece of work. Special appreciation goes to my lectures and panellists in the School of Public Health department of Environmental Health and Disease Control during proposal presentation for their input and recommendations.

I acknowledge Dr. Stephen Ndolo the Director Medical Services on behalf of the County Government of Makueni Department of Health for granting me the consent to conduct the study in his area of jurisdiction. I thank Dr. Antony Masila the Medical Superintendent Kibwezi Subcounty Hospital for permitting me to pretest the study questionnaires. I also appreciate Mr. Silvester Waita the Facility
In-Charge Emali Model Health Centre and Dr. David Kasanga the Medical Superintendent Makindu Sub-County Hospital for consenting to have their respective facilities as study areas. I also acknowledge my research assistants Winnie Mulu, Mophat Maitha and Elizabeth Mutinda for their overwhelming support in the data collection process. I am also indebted to the study participants for their acceptance to participate in the study without whom there would be no study. May God bless you and keep you safe always. To anyone not mentioned here who participated directly or indirectly in the development of the protocol and production of this final work, I say "Thank you!" Lastly, I would not fail to thank the Almighty God for life, grace, strength and fortitude to accomplish this work.

\section{Source of Funding: None}

\section{Ethical Approval: Approved}

\section{REFERENCES}

1. Rai S, Mahapatra B, Sircar S, Yujwal P R, Venkatesh S, Shaukat M, et al. Adherence to Antiretroviral Therapy and Its Effect on Survival of HIV-Infected Individuals in Jharkhand, India. PLoS One. 2013; 8(6): 1$7 . \quad$ Available from: doi: 10.1371/journal.pone.0066860.

2. Heestermans $\mathrm{T}$, Browne $\mathrm{J}$, Aitken $\mathrm{S}$ et al. Determinants of adherence to antiretroviral therapy among HIV-positive adults in subSaharan Africa: a systematic review. BMJ Global Health.2016; 1(4): 1-25. Available from: doi: 10.1136/bmjgh-2016000125.

3. Kapiamba G, Thembekile M, Mphuthi D. Antiretroviral adherence and virological outcomes in HIV-positive patients in Ugu district, KwaZulu-Natal province. African Journal of AIDS Research. 2016; 15(3): 195-201.

4. National AIDS Control Council. 2018 Kenya HIV Estimates Report. Ministry of Health. 2018

5. Kenya National Bureau of Statistics [KNBS]. Makueni County Statistical 
Abstract. Nairobi: Kenya National Bureau of Statistics. 2015.

6. World Health Organisation [WHO]. SDG 3: Ensure healthy lives and promote wellbeing for all at all ages [Internet]. 2018 [cited 2021 Oct 14]. Available from Error! Bookmark not defined.

7. Soomro N, Fitzgerald G, Seeley J et al. Comparison of Antiretroviral Therapy Adherence Among HIV-Infected Older Adults with Younger Adults in Africa: Systematic Review and Meta-analysis. AIDS and Behaviour. 2019; (23): 445-458.

8. Ammon N, Mason S, Corkery J M. Factors impacting antiretroviral therapy adherence among human immunodeficiency viruspositive adolescents in Sub-Saharan Africa: a systematic review. Public Health. 2018. (157): 20-31. Available from: doi: 10.1016/j.puhe.2017.12.010.

9. Croome N, Ahluwalia M, Hughes L D et al. Patient-reported barriers and facilitators to antiretroviral adherence in sub-Saharan Africa. AIDS. 2017; 31(7): 995-1007. Available from: doi: 10.1097/QAD.0000000000001416.

10. Mengesha M M, Ajema D, Teshome A et al. The association between diagnosis disclosure and adherence to antiretroviral therapy among adolescents living with HIV in sub-Saharan Africa: a protocol for systematic review and meta-analysis. Sytematic Reviews. 2020; 9(1):160. Available from: doi: 10.1186/s13643-02001420-8.

11. Bijker R, Jiamsakul A, Kityo $\mathrm{C}$ et al. Adherence to antiretroviral therapy for HIV in sub-Saharan Africa and Asia: a comparative analysis of two regional cohorts. Journal of International AIDS Society. 2017; 20(1): 21218. Available from: doi: 10.7448/IAS.20.1.21218.

12. Chirambo L, Valeta $M$, Mary $\mathrm{T}$ et al. Factors influencing adherence to antiretroviral treatment among adults accessing care from private health facilities in Malawi. BMC Public Health. 2019; (19): 1382.

13. Mukui I N, Ng'ang'a L, Williamson J, Wamicwe J N, Vakil S, Katana A, et al. Rates and Predictors of Non-Adherence to Antiretroviral Therapy among HIV-Positive Individuals in Kenya: Results from the Second Kenya AIDS Indicator Survey,
2012. PLoS ONE. 2016; 11(12). Available from: doi: 10.1371/journal.pone.0167465.

14. Rouhani S A, O'Laughlin K N, Faustin Z M et al. The role of social support on HIV testing and treatment adherence: A qualitative study of HIV-infected refugees in southwestern Uganda. Global Public Health. 2017; 12(8): 1051-1064. Available from: doi: 10.1080/17441692.2015.1132472.

15. Agbaji O O, Abah I O, Falang K D et al. Treatment Discontinuation in Adult HIVInfected Patients on First-Line Antiretroviral Therapy in Nigeria. Current HIV research. 2015;13(3): 184-92.

16. Semvua S K, Orrell C, Mmbaga B T et al. Predictors of non-adherence to antiretroviral therapy among HIV infected patients in northern Tanzania. PLoS One.2017; 12(12): 1-17. Available from: doi: 10.1371/journal.pone.0189460.

17. Kim M H, Mazenga A C, Yu X et al et al. High self-reported non-adherence to antiretroviral therapy amongst adolescents living with HIV in Malawi: barriers and associated factors. Journal of the International AIDS Society. 2017; 20(1): 112. Available from: doi: 10.7448/IAS.20.1.21437.

18. Adejumo O A, Malee K M, Ryscavage P et al. Contemporary issues on the epidemiology and antiretroviral adherence of HIV-infected adolescents in sub-Saharan Africa: a narrative review. Journal of the International AIDS Society.2015; 16(18): 119. Available from: doi: 10.7448/IAS.18.1.20049.

19. Mûnene E, Ekman B. Socioeconomic and clinical factors explaining the risk of unstructured antiretroviral therapy interruptions among Kenyan adult patients. AIDS Care. 2016; 28(9): 11101118. Available from: doi: 10.1080/09540121.2016.1140890.

20. Tiruneh Y M, Galárraga $O$, Genberg B et al. Retention in Care among HIV-Infected Adults in Ethiopia, 2005- 2011: A MixedMethods Study. PLoS One. 2016; 11(6): 117. Available from: doi: 10.1371/journal.pone.0156619.

21. Yotebieng M, Thirumurthy H, Moracco K E et al. Conditional Cash Transfers to Increase Retention in PMTCT Care, Antiretroviral Adherence, and Postpartum Virological 
Martin Owuor Ochieng et.al. Factors associated with adherence to antiretroviral drugs among HIV positive patients attending selected comprehensive care centers in semi-urban, Kenya.

Suppression: A Randomized Controlled Trial. Journal of Acquired Immune Deficiency Syndromes. 2016; 72(2): 124-9. Available from:

doi: 10.1097/QAI.0000000000001062.

22. Tweya H, Gugsa S, Hosseinipour $M$ et al. Understanding factors, outcomes and reasons for loss to follow-up among women in Option B+ PMTCT programme in Lilongwe, Malawi. Tropical Medicine \& International Health. 2014; 19(11): 13601366. Available from: doi: 10.1111/tmi.12369.

23. Costenaro P, Penazzato M, Lundin R et al. Predictors of Treatment Failure in HIVPositive Children Receiving Combination Antiretroviral Therapy: Cohort Data From Mozambique and Uganda. Journal of the Pediatric Infectious Diseases Society.2015; 4(1): 39-48. Available from: doi: 10.1093/jpids/piu032.

24. Gesesew H A, Ward P, Woldemichael K et al. Early mortality among children and adults in antiretroviral therapy programs in Southwest Ethiopia, 2003-15. PLoS One. 2018;13(6); 1-17. Available from: doi: 10.1371/journal.pone.0198815.

25. Ssebunya R, Wanyenze R K, Lukolyo H et al. Antiretroviral therapy initiation within seven days of enrolment: outcomes and time to undetectable viral load among children at an urban HIV clinic in Uganda. BMC Infectious Diseases.2017;17(1), 439. Available from: doi: 10.1186/s12879-0172550-2.

26. Dos S M, Wolvaardt G. Integrated intervention for mental health co-morbidity in HIV-positive individuals: A public health assessment. African Journal of AIDS Research (AJAR).2016; 15(4): 325-331. Available from:

DOI: 10.2989/16085906.2016.1229683.

27. Mangesho P E, Reynolds J, Lemnge M et al. "Every drug goes to treat its own disease..." - a qualitative study of perceptions and experiences of taking anti-retrovirals concomitantly with anti-malarials among those affected by HIV and malaria in Tanzania. Malaria Journal. 2014; 13(1): 353-369. Available from: doi: 10.1186/1475-2875-13-491.

28. Eshun-Wilson I, Rohwer A, Hendricks L et al Being HIV positive and staying on antiretroviral therapy in Africa: A qualitative systematic review and theoretical model. PLoS One. 2019; 14(1): 1-30. Available from: doi: 10.1371/journal.pone.0210408.

29. Dowse R, Barford K, Browne S H. Simple, illustrated medicines information improves ARV knowledge and patient self-efficacy in limited literacy South African HIV patients. AIDS Care. 2014; 26(11):1400-6. Available from: doi: 10.1080/09540121.2014.931559.

30. Okawa S, Mwanza K S, Mwiya M et al. Psychological well-being and adherence to antiretroviral therapy among adolescents living with HIV in Zambia. AIDS Care. 2018; 30(5): 634-642. Available from: doi: 10.1080/09540121.2018.1425364.

31. Mprah A. Knowledge, opinions, and experiences of stigma as a barrier to antiretroviral therapy adherence among HIV community volunteers and health care givers in an urban slum, in Uganda. Annals of Tropical Medicine \& Public Health. 2016; 9(5): 331-339. Available from: doi:10.4103/1755-6783.190180.

32. Ramadhani H O, Muiruri C, Maro V P et al. Association of knowledge on ART line of treatment, scarcity of treatment options and adherence. BMC Health Services Research. 2016;16: 1-7. Available from: doi: 10.1186/s12913-016-1483-6.

33. Cochran W G. Sampling Techniques. John Wiley and Sons Inc. New York;1963.

34. Reda A A, Biadgilign S. Determinants of Adherence to Antiretroviral Therapy among HIV-Infected Patients in Africa. AIDS Research and Treatment. 2012: 574656. Available from: doi: 10.1155/2012/574656.

35. Vreeman R C, Wiehe S E, Pearce, E C et al. A systematic review of pediatric adherence to antiretroviral therapy in low- and middleincome countries. The Paediatric Infectious Disease Journal. 2008; 27(8): 686-91. Available from: doi: 10.1097/INF.0b013e31816dd325.

36. Nieuwkerk P T, Oort F J. Self-reported adherence to antiretroviral therapy for HIV1 infection and virologic treatment response: a meta-analysis. Journal of Acquired Immune Deficiency Syndromes. 2005; 38(4): 445-448.

37. Liu H, Golin C E, Miller et al. A comparison study of multiple measures of adherence to HIV protease inhibitors. Annals of Internal Medicine. 2001; 134(10): 968-77. 
Martin Owuor Ochieng et.al. Factors associated with adherence to antiretroviral drugs among HIV positive patients attending selected comprehensive care centers in semi-urban, Kenya.

38. Mannheimer S B, Mukherjee R, Hirschhorn $\mathrm{L} \mathrm{R}$ et al. The CASE adherence index: A novel method for measuring adherence to antiretroviral therapy. AIDS Care. 2006; 18(7): 853-861. Available from: doi: $10.1080 / 09540120500465160$.

39. Joint United Nations On AIDS [UNAIDS]. An Ambitious Treatment Target to Help End the AIDS Epidemic. Available from:

HYPERLINK "http://www.unaids.org/en/resources/docum ents/2017/90-90-90" It "blank" http://www.unaids.org/en/resources/docume nts/2017/90-90-90. [Accessed 1 ${ }^{\text {st }}$ March 2018].
40. Government of Makueni County. Makueni County Vision 2025. Makueni: Government of Makueni County. 2016.

41. Ministry of Health $[\mathrm{MoH}]$. Kenya Aids Strategic Framework 2014/20152018/2019. Nairobi: Ministry of Health [MoH]. 2014.

How to cite this article: Ochieng MO, Kikuvi G, Mokaya D. Factors associated with adherence to antiretroviral drugs among HIV positive patients attending selected comprehensive care centers in semi-urban, Kenya. Int J Health Sci Res. 2021; 11(12):134-151. DOI: https://doi.org/10.52403/ ijhsr.20211219

$* * * * * *$ 